\title{
A purposeful approach for measuring greenhouse gas emissions of material flow accounts for the accomplishment of territorial sustainable development and cultural economy goals on climate. The case of the Basque Country
}

\author{
Macarena Larrea Basterra ${ }^{1,2}$ D $\cdot$ Roberto Alvaro-Hermana ${ }^{1,2}$. \\ Nuria Ceular-Villamandos ${ }^{3} \cdot$ Noel M. Muniz ${ }^{1,2}$
}

Received: 6 May 2020 / Accepted: 12 July 2021 / Published online: 9 September 2021

(c) The Author(s) 2021

\begin{abstract}
This study aims at developing a purposeful approach for estimating greenhouse gas (GHG) emissions and its possible use to recreate alternative scenarios that might potentially facilitate the attainment of the material productivity (MP) ratio needed for achieving territorial sustainable development (SDGs) and circular economy goals on climate. The propounded method associates these two key concepts (GHG-MP) with the domestic material consumption (DMC) and international trade of materials, including product life cycle emissions in the overarching GHG total estimation. Developed utilizing the United Nations Framework Convention on Climate Change (UNFCCC) and diverse data, linked to the suggested scheme, from the Basque Country (Spain), this work also relies its scientific foundation upon leading literature in this field to align territorial models of production and consumption with a more localized measurement of GHG emissions. According to its results, the emissions estimated allow advising more contextualized scenarios for the potential achievement of local MP target indicator, when expressed as the amount of economic output_— based on gross domestic product (GDP)— generated per unit of materials consumed and traded_—in terms of DMC. From a theoretical perspective, this work contributes to the local strategic management of circular economy research and 2030 Agenda, particularly on the subject of measuring progress in the achievement of territorial climate and circular economy goals. From a utilitarian perspective, the findings comprise promising implications for both multilevel policy makers and public/private organizations that further sustainable development and actions against climate change.
\end{abstract}

Keywords Climate change $\cdot$ Greenhouse gas emissions $\cdot$ Material productivity $\cdot$ Domestic material consumption · Circular economy $\cdot$ Sustainable development goals

Macarena Larrea Basterra

macarena.larrea@orkestra.deusto.es

Extended author information available on the last page of the article 


\section{Introduction}

Among all the environmental challenges that impel governments at all levels to achieve ambitious but urgent goals within the next ten to thirty years, the fight against climate change undoubtedly ranks first in drawing critical attention and resources.

This global crusade, for curbing the most tremendous threat ever faced by modern civilization, embraces countless frontlines. Materialized as progressive political endeavors, in the case of the European Union (EU), these collective courses of actions currently range from reducing net greenhouse gas (GHG) emissions by $55 \%$ in 2030 (European Commission, 2020a) to redesigning products and processes to scale up industrial circularity toward a more competitive and climate-neutral economy by 2050 (European Commission, 2020b). On these subjects, the accountability and report of GHG emissions play a common key role to evaluate the levels of progression and achievement of territorial sustainable development goals on climate and circular economy.

In this vein, the present work posits a purposeful approach for measuring greenhouse gas $(\mathrm{GHG})$ emissions and generating alternative scenarios that might potentially facilitate the attainment of local material productivity (MP) target ratios-in terms of GHG emissions-needed for achieving territorial sustainable development (SDGs) and circular economy goals on climate. The scheme here proposed links this binomial conception (GHG-MP) to the domestic material consumption (DMC) and international trade of materials, including product life cycle emissions in the comprehensive GHG combined estimation, seeking to simplify the process of allocating emissions at regional level.

In this sense, although the search for emission factors might turn into a complex task, this approach will incorporate simplicity providing clarity to facilitate awareness of what products are among the most critical ones in terms of local generation of GHG emissions, as well as their means of transportation, and countries of origin, among others. Moreover, it will underscore the essential importance of recycling materials, given their lower carbon footprint, and balancing emissions of imports, exports, and local production, while acknowledging the responsibility between consumers and producers.

Based on the United Nations Framework Convention on Climate Change (UNF$\mathrm{CCC}$ ) and various territorial data from the Basque Country (Spain), this paper assembles its scientific basis with prevalent academic works in this realm of knowledge to harmonize region-specific models of production and consumption with more localized measurements of GHG emissions.

Finally, it is worth to say that this research is the corollary of a study conducted by Orkestra-Basque Institute of Competitiveness (University of Deusto) for the Basque Public Society for Environmental Management of the Basque Government (Ihobe), which considered the need of developing a more precise tool for calculating territorial GHG emissions from the perspective of local consumption.

The rest of this paper is organized as follows: The succeeding section reviews previous findings linked to the variables that comprise the propounded approach. The hypotheses of the research are exposed subsequently, being followed by the method description and exposition. This work concludes with the account of the study results, the elucidation of the discussion section, and the exposition of main conclusions, implications, limitations, and further research in the field. 


\subsection{The estimation of greenhouse gas (GHG) emissions and material productivity (MP) in a territory}

Since 1997, the United Nations Framework Convention on Climate Change (UNFCCC), in line with the Kyoto Protocol, requests from its Parties to submit annually their national greenhouse gas inventories (NGGI) to its secretariat for the purpose of keeping track of national performances and advancements in GHG emissions reduction commitments (UNFCCC, 2020).

In a complementary manner, the Intergovernmental Panel on Climate Change (IPCC)the most authoritative scientific voice on this subject-with its Task Force on National Greenhouse Gas Inventories (TFI), developed in 2006 the "IPCC Guidelines for National Greenhouse Gas Inventories." This elaborated methodology for estimating and reporting more accurately GHG emissions is currently utilized, in its refined version, by the UNFCCC's parties to prepare their national GHG inventories yearly (IPCC, 2019).

In its varied sections, this inventory has to impute both GHG emissions and removals generated within its country's mainland and overseas territories under national jurisdiction. This territorial perspective seems to add complexity to the count, but it is not so much the case. For instance, as a basic exemplification, emissions from road vehicles have to be included in the national accounts of the country where the fuel producing those gases was loaded. Likewise, those emissions from the combustion or decay of timber products ought to be tallied in the inventory of the country where that wood has been harvested; however, according to the IPCC Guidelines for National Greenhouse Gas Inventories, those associated with international transport needn't be included in any NGGI.

In general terms, GHG emissions related to fuel combustion has to be allocated to the country's account where the emissions have been released. In this sense, Peters and Hertwich (2006) refer to them as territorial-based inventories (TBI). Despite this fact, nations generally build these UNFCCC inventories allocating emissions to technology-based sectors, such as energy or transport (Peters \& Solli, 2010), being the basis for the measuring of their carbon footprints - GHG emissions produced due to the process of sectors' activity.

Since the adoption of the Kyoto Protocol on December 11, 1997, a fair amount of academic literature in this field has drawn attention to the difficulties, limitations and downsides of this method, mainly because manufacturers turn out to be the solely responsible for GHG emissions and because only emissions produced within a region or country are finally considered (Bastianoni \& Pulselli, 2004; Lenzen et al., 2007; Peters, 2008).

According to Peters (2008), its major limitations lie in the consideration that international transportation is not allocated to inventories. That certainly hastens carbon leakages, namely transferences of production to other countries with more lax emission constraints. As responsible consumers concerned about recycling and the environment, society as a whole does not seem to be very aware of this when it comes to local consumption. In this sense, Bastianoni and Pulselli (2004) recognize that the shared responsibility between consumers and producers is not considered in the calculation of UNFCCC inventories and that is something that deserves utmost attention (Lenzen et al., 2007).

In addition to the territorial scope, Peters and Hertwich (2008) claim for a second method to tally GHG emissions, which is known as the production-based approach. This model considers emissions from resident institutional units (e.g., households or legal and social entities) through the lens of the national economic accounts. Hence, implicitly, under this scheme pervades both the aforementioned territorial-boundary approach and a rationale based on gross domestic product (GDP). 
These so-called production-based inventories (PBI) account for some of the critiques raised against the UNFCCC territorial-based inventories since this approach assigns, for instance, international aviation and shipping emissions to the country of the relevant vessel's operator or, in the case of tourism emissions, to the country of residence of the tourists (Barrett et al., 2013).

Furthermore, the PBI comprises the emissions associated with domestic withdrawals (DW)___omestic extraction (DE) as the amount of raw material (excluding water and air), in physical weight, extracted from nature for its use in the economic activity (Eurostat, 2017), which cover activities such as manufacturing processes and energy consumption, including in some cases imports of electricity, thus accounting for carbon leakage (Barrett et al., 2013). The latter happens to be particularly reasonable since, in a regional model, there is a comprehensible need of including emissions of the national electricity system; otherwise, there would be an underestimation of emissions.

On the other hand, the PBI approach seems to evince one salient drawback: It enables countries to promote introductions of price signals, such as carbon taxes on production, as a means to reduce inventories. This measure turns out to be positive for local emissions but could mean higher global ones due to carbon leakage (Peters, 2008).

A third alternative approach is consumption-based inventories (CBI), which consider the emissions associated with consumption of goods and services in each country (Ahmad \& Wyckoff, 2003). The CBI differs from the TBI and PBI inventories in the way it minds the emissions from imports and exports (Peters, 2008; Peters \& Hertwich, 2006, 2008), which may be considered fairer (Larrea Basterra \& Álvaro Hermana, 2019).

The rationale behind this consideration grounds on the fact that the CBI includes in its count the emissions resulting from the production of those goods consumed by the resident units, plus the consumption of abroad units within the territorial and sovereign boundaries of its nation. Thus, GHG emissions, as a result of consumption, are included in CBI regardless of the origin of the production process chain in which the goods finally consumed were manufactured. On this subject, Peters and Hertwich (2006) state that consumers should be more aware of the emissions associated with their own consumption, which could lead to taking actions that motivate companies and more consumers to reduce emissions and the environmental impact of the goods consumed.

The view through this promising lens has moved several government statistical agencies to utilize the CBI approach for the calculation of their national GHG inventories. That is the case of Australia and the UK (Edens et al., 2011; Peters, 2008). Likewise, and more recently, Austria (Barrett et al., 2013) and New Zealand (Steininger et al., 2018) have also carried out studies estimating CBI for their accounts.

Similarly, the US state government of Oregon, and the cities and counties of San Francisco and Portland have formulated CBI models, while in Europe, the Belgian region of Flanders and the country of Scotland have joined to the employment of this GHG inventory approach (Chandrakumar et al., 2019; USDN, 2020; Vito, 2017). Even at the local level, numerous cities have currently carried out their CBI (Broekhoff et al., 2019; Zero waste Scotland, 2015).

Emission inventories, thus, turn out to be very effective tools to evaluate the evolution of GHG emission reduction targets for a country or territory. Nowadays, climate strategies aim at promoting economic growth while reducing GHG emissions and the overuse of natural resources, actions that can be inherently interconnected with each other thanks to one concept known as material productivity. 
In this sense, material productivity is expressed, according to its definition, as the amount of economic output-in terms of gross domestic product (GDP)—generated per unit of materials consumed_— pertaining to domestic material consumption (DMC).

Through consumption-based inventories, which are estimated on the basis of domestic material consumption (DMC), and the complementary utilization of material productivity, these three single concepts gain further significance given its potential combined use to help measure and monitor key territorial targets pertaining to core sustainable development goals associated with responsible industrial circularity and competitive climate-neutral economy. The methodology that supports this paper will be developed within the next sections addressing this assumption.

\subsection{Domestic material consumption (DMC), international trade of materials, and product life cycle as accounting items in the consumption-based inventories (CBI) of GHG total emissions estimation for a territory}

The allocation scope of consumption-based inventories (CBI) seems to answer questions such as how to assign GHG international transportation and national bunker fuel emissions to a particular nation, or how to address territorial competitiveness concerns and encourage its technology diffusion associated with the control of GHG emissions, or how to contribute to reduce the relevance of GHG emission commitments for developing countries (Larrea Basterra \& Álvaro Hermana, 2019).

Despite its potential, the CBI approach also exhibits signs of seeming limitations. First, consumption-based inventories require more complex calculations and hence assumptions of combined effects on total aggregated tally, adding further variability to the model. Secondly, the shift from production to consumption model does not remedy how to deal with the lack of shared awareness, from both consumers and manufacturers, regarding reciprocal sustainable responsibility. Finally, for its precise estimation, it is necessary to delimit a specific geopolitical space, be it national or regional (Peters \& Hertwich, 2008).

All these considerations give meaning to a specific inventory concept, for calculating greenhouse gas emissions inventories, that is, complemented by utilizing three equally essential notions: the domestic material consumption, the international trade of material, and the product life cycle scope.

Already mentioned in previous lines, the domestic material consumption (DMC) is an index employed to estimate the total amount of material directly consumed by a concrete economy. According to the European Statistical Office - Eurostat - the DMC is defined as an indicator of the total amount of material directly used in a specific economy, being calculated by subtracting all physical exports pertaining to a territory to the total material input of its economy. Hence, rooted in the economy-wide material flow accounts (EWMFA), the DMC in tons per capita facilitates comparative analysis of material consumption among nations normalized with the population (Eurostat, 2020a).

An extra factor to count on for the CBI tally is one that is recurrently mentioned today in mainstream circular economy research: the product's life cycle focus from the life cycle thinking (LCT) perspective of circular economy. As stated by Mont and Bleischwitz (2007), the LCT considers all environmental aspects of a product process from cradle to grave and evaluates all the possibilities for that product to ameliorate environmental impact throughout its life cycle stages, which are-according to circular economy canon-extraction of raw materials, design and production, packaging and 
distribution, use and maintenance, and end of use and disposal (UNEP/SETAC, 2007). In this sense, the CBI comprises all the GHG emissions of a product taking place in all these phases.

Finally, the international trade of materials is integrated to the GHG total emissions estimation for a territory given its strong impact on the environment of those countries with asymmetric trade balances where imports, both of basic inputs and of medium or advanced stages in the manufacturing processes__ as well as products for final consumption-represent a considerable amount of the greenhouse gas emissions citizens and companies end up causing as final users and consumers (Steen-Olsen et al., 2012).

In literature, the construction of a consumption-based inventory (CBI) is computed by converting a territorial-based inventory (TBI) — generally following the UNFCCC's guideline-into a production-based inventory (PBI) consistent with the System of National Accounts. Next, the PBI is reallocated to CBI by employing input-output analysis (IOA) or multiregional input-output analysis (MRIOA) (Ahmad \& Wyckoff, 2003; Chen, et al., 2018; Peters, 2008), which implies the assignment of emission factors to imported and exported products.

Additionally to MRIOA, there are two main approaches to determine the environmental impacts of imported goods and services. The first one considers total embodied emissions in bilateral trade (EEBT) between regions and the second one considers both trades to intermediate and final consumption (Wiedmann, 2009). None of them is wrong or right; they just allocate emissions differently.

Peters (2008) also cites other methods to construct CBI. The first one considers that human demand expresses the ecological footprint (Kitzes et al., 2007; Reyes, 2012). The second one, MRIO, employs multiregional input-output tables for trading to final consumption and determines endogenously trade to intermediate consumption (Turner et al., 2007) and the third one is a hybrid approach, which resolves the boundary selection problem in life cycle assessment (Wiedmann et al., 2007).

In 2009, a European project identified the Environmentally Extended Multi-Region Input-Output analysis (EE-MRIOA) as a favorable approach to provide a comprehensive assessment of the global economy and analyze its effects on the environment (Suh et al., 2004). This methodology is the basis of the C4O Cities Inventories initiative (C40, 2018). It analyzes household, government, and business capital expenditure from national and regional economic accounts and uses average GHG emission factors for each consumption category considering the location where the goods and services are produced (Barrett et al., 2013).

C40 (2018) calculated the life cycle GHG emissions to a municipal level, including a comprehensive assessment of purchases employing input-output analysis (IOA).

To broaden the data coverage, Larsen and Hertwich (2009) propose the long-term consumption-based accounting model (LCBA), and more recently, Chen et al. (2018) suggest an alternative indicator considering the role and dynamics of capital stock in the global production structure within the multiregional input-output framework. The approach of Chen et al. (2018) encompasses the fuel life cycle emissions of goods and services and is based on households, government, and companies spendings. It encompasses the emissions from production, pre-purchase transportation, wholesale, and retail, use and cost-consumer disposal.

In this line, the CBI of the State of Oregon (USA) accounts for total GHG emissions from producing, using, and disposing of a product (USDN, 2020). 


\subsection{Sustainable development goals and territorial circular economy actions against climate change}

The germ of the modern conception of sustainability can be clearly recognized in the text of the Brundtland Report (WCED, 1987). Better known as Our Common Future, this statement portrays the cornerstone of this contemporary paradigm not only in the strict conceptual sense of the term economic, social, and environmental "sustainable development," but also in its foundations based on improving the well-being of everyone in a global community. Its emphasis on justice and social equity on a worldwide scale reveals its cross-border scope for sustainability and how it can positively or negatively compromise the prosperity of citizens from other countries, as a principle of fair distribution of global well-being (WCED, 1987).

Rooted in these postulates, on September 25, 2015, the member countries of the United Nations reached a general agreement on a new common agenda of economic, social, and environmental sustainability. Thus, was born the current 2030 Agenda for Global Sustainable Development and its 17 goals and 169 targets to be met by the end of the referred year (UN, 2015).

In its text, specifically in paragraphs 31 and 32, the SDGs claim for a global response to climate change-banking on the United Nations Framework Convention on Climate Change as the cardinal multinational forum for negotiating actions to tackle global warming and its disastrous environmental degradation-calling for the acceleration in the decline of GHG emissions and adaptation to the potential detrimental effects that these are certainly bringing to present and future generations. Indeed, it encourages holding the rise in global average temperature below 2 degrees Celsius, or 1.5 degrees Celsius above preindustrial levels (UN, 2015).

The SDGs give a very high priority to the fight for climate change, even focusing one of its 17 goals entirely on this global problem: Goal 13. Take urgent action to combat climate change and its impacts. However, in the integrity of its text, the 2030 Agenda deals with the fight to combat climate change in a transversal way. Thus, in the definition of the measures that should be taken to achieve the fulfillment of its 17 goals, the following targets that are directly binding with the reduction of GHG emissions stand out: $1.5 ; 8.4 ; 9.4 ; 11.6 ; 12.4 ; 12 . c ; 13.2 ; 13.3 ; 13 . a$; and 17.7 (UN, 2015). Nowadays, many of these measures are contemplated locally in the development strategies of multiple European territories, such is the case of the Basque Country and its plan called Basque Contribution to the 2030 Agenda for Sustainable Development (Basque Government, 2018a).

On the other hand, the present reality of a globalized and hyper-connected world forces organizations to understand a series of transformation dynamics in terms of economic, social, and environmental sustainability that urgently demand transformation; such is the case of the application of the circular, responsible, and sustainable economy in production processes.

Better known as circular economy, this approach supposes a paradigm shift in the way of employing natural resources and caring for the environment. In this circular model, the life cycle of products and materials are kept in process for the longest time possible, while waste is reduced to a minimum. Resources are repeatedly reintroduced into the production cycle, creating value, whereas goods reach the end of their useful life. Products are designed and manufactured considering their reusable, recyclable, and sustainable management and efficient use of natural resources and waste generation. 
A more circular approach (e.g., in biomass, metals, cement, plastic and glass among others) is essential to reduce GHG emissions (Pratt et al., 2016). It covers energy production and use, emissions of greenhouse gases and pollutants to the air, food intake and food waste, accumulation of material stocks, the use of raw materials in industry and recycling among others (Eurostat, 2020b).

In line with the 2030 Agenda, European territories have combined several of its SDGs targets, associated with the reduction of GHG emissions, with significant circular economy actions against climate change. That is the case of the Basque Country, which as a territory has mapped out its own Circular Economy Strategy of Euskadi 2030 (Basque Government, 2018b) and begun to implement it through its Environmental Management Agency called Ihobe.

This strategy has set in a prominent place the 2030 Agenda and its crosswise Goal 13, linking it to the abatement of territorial GHG emissions, which is clearly observable in the description of its local challenges: Ch.1 Promoting the creation of new, more circular business models (SDG 9); Ch.2 Innovating in materials—advanced and renewable-processes and products (SDG 9); Ch.5 Encouraging a more circular consumption model (SDG 12); Ch.6 Lessening food waste (SDG 12); Ch. 8 Intensifying the reuse, recycling and recovery of waste (SDG 11); and Ch. 9 Escalating the use of secondary raw materials (SDG 15) (Basque Government, 2018b; Ihobe, 2020).

In this context, Ihobe requested, last year 2019, the institutional collaboration of the Basque Institute of Competitiveness (Orkestra) for the identification of a purposeful approach for measuring greenhouse gas emissions of material flow accounts for the accomplishment of territorial sustainable development goals on climate and circular economy for the Basque Country, this being the basis of the present work through its research, analysis and results obtained, which ends up being a primary tool for the preparation of current local GHG emission inventories.

\section{Methodology}

\subsection{Hypothesis for modeling the approach to measuring territorial GHG emissions of material flow accounts}

As indicated in Introduction, the object of the present investigation is to develop a purposeful approach for estimating greenhouse gas (GHG) emissions through more accurate accounting of GHG inventories and its possible use to recreate alternative scenarios that might potentially facilitate the attainment of the material productivity (MP) ratio needed for achieving territorial sustainable development goals (SDGs) on climate and circular economy.

Under this premise, the hypotheses sought to be answered are the following:

(1) Given their own specifications, at a comparative level, it is probable that the consumption-based inventories (CBIs) and the production-based inventories (PBIs) behave in a differentiated or similar way yielding accounting results. Therefore:

Hypothesis 1 The consumption-based inventories (CBIs) and the production-based inventories (PBIs) tend to yield dissimilar accounts in industrial economies. 
(2) When using a GHG emissions inventory approach based on the consumption of a territory, it is necessary to incorporate into this approach a product life cycle scope that considers including among its constituent parts the structure of its total imports and exports, even though it might produce a positive or negative variation. Thus:

Hypothesis 2 The consumption-based inventories (CBIs) may increment if life cycle emissions factors are considered. It will depend on the structure of the imports and exports of a territory.

(3) A more globalized economy leads to higher emissions. However, it will depend on the means of transportation and product-emission factors determined by country or territory. Hence:

Hypothesis 3 The more globalized a territorial economy is, the more it will lead to higher emissions.

(4) Once incorporated into the accounting of consumption-based inventories (CBIs), the product-emission factors and the means of transports for them significantly contribute to determining which precise materials or products are responsible for a higher or lower GHG emission for a territory, in accounting terms.

Hypothesis 4 This compound model can help more clearly reveal which materials/products lead to higher emissions for a territory.

Hypothesis 5 This compound model can contribute to raise awareness in society of what it consumes, in terms of GHG emissions, and reallocate GHG emissions to the specific responsible agents, namely importers, producers, or consumers.

Hypothesis 6 This compound model can help provide inputs for policy makers to take more accurate measures in relation to the achievement of territorial sustainable development and circular economy goals linked to GHG emissions.

\subsection{Construction of the model proposal: materials involved in the structure of the approach}

The methodology employed in this paper utilizes four primary data sources. First, the territorial TBI, which in the case of the Basque Country is provided by its Department of the Environment, Territorial Planning and Housing (Gobierno Vasco, 2019). Given the regional focus of this case study, both imports and exports from the rest of Spain (RC) and the world (RW) are considered.

In this sense, the statistics utilized for the RW classify products according to tariff codes (European Commission, 2019), facilitating the assignment of emission factors to them. For its part, the Tax Agency Office of the Government of Spain registers the imports and exports data in economic $(€)$ and physical (tons) terms (Gobierno Vasco, 2019). Here, for 
this model proposal, it is employed in physical terms; however, the data obtained are disaggregated by source of origin (foreign countries) delivered to the receiving region studied in Spain, the Basque Country.

In the case of international imports, it is used data from 2016 in detail, covering 23,887 purchases from 182 countries of origin, 8 different means of transport, and 1161 different product codes. In the case of international exports, figures are employed from the same year comprising 33,137 sales delivered to 220 destinations by 8 different means of transport and 1064 product codes.

Conversely, the territorial trade movements__exports and imports from and to the Basque Country - do not follow the foregoing classification of products according to tariff codes (European Commission, 2019), but a categorization based on commercial activity, which complicates the estimation of emission factors. This circumstance is accentuated by the low level of data disaggregation. Thus, certain assumptions, concerning the methodology here stated, are later made to surmount this hurdle, and provide reasonable compatibility between classifications. In any case, this data source, known as C-Intereg (C-Intereg, 2019), furnishes the imports and exports from and to the remaining Spanish autonomous communities and provinces by 5 different means of transport (Agencia Tributaria, 2019).

Next, emission factors must be taken into account (EFs). These provide representative values of the amount of GHGs emitted to the atmosphere per unit of activity- whether it is referring to materials or products-banking on the life cycle inventory analysis (LCI analysis) of the products.

The EFs search has been carried out with the life cycle assessment software called SimaPro. The central database utilized was ecoinvent (2019) given its potential use to compare data with a territorial scope of EFs. On this subject, even though the focus was on global values, in those cases where these were not available, it was assumed a "rest of the world" or European Union value perspective; while in the marginal cases when no information was found, other databases such as LCA food DK, EU, and DK input-output database, Swiss input-output database, Agrifood print, USLCI, and Industrial data 2.0. have been employed. Moreover, the emission factors associated with the different means of transport were obtained from the ecoinvent database.

Finally, the fourth constituent in the scheme is the assessment of the distances traveled by the imported goods from the capital city of the country of origin to a precise geographical point-epicenter of the receiving territory. For the purposes of this study, the selected point for the Basque Country was the Municipality of Mondragon. The data sources utilized to calculate this factor were mainly GeoDatos, for the rest of the world, and Ditecosa, for the distances between Spanish provincial capital cities.

\subsection{The life cycle related methodology}

The approach presented in this paper considers the TBI and the GHG emissions associated with the imports and exports to calculate a CBI. This opens doors to the evaluation of impacts on the achievement of specific sustainable development and circular economy goals in terms of GHG emissions. This tool involves three main phases (see Fig. 1).

The first phase consists of reviewing the EFs of the different products that will be multiplied by the import and export material flows to estimate its carbon footprint $C F$, as the next formula shows: 


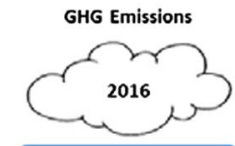

Phase 1

\section{Carbon footprint}

- Imports and exports flows

- RegionalGHG inventories

- Emissions factor

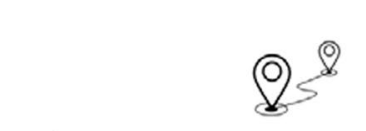

Phase 2

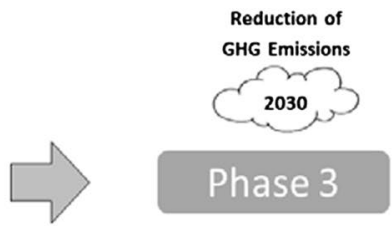

Impact of Circular Economy

- Circular Economygoals

- Impact on imports

- Impact on exports

Temporal horizon 2016

Fig. 1 Phases for the proposed methodology. Source: the authors

$$
\mathrm{CF}=\sum_{i=1}^{l} \text { Product }_{i} \times \mathrm{EF}_{i}
$$

where Product ${ }_{i}$ represents the volume of a product category_- tariff codes with 4 digits for $\mathrm{RW}$ and regional codes for $\mathrm{RC}$ - measured in kilograms, and the $\mathrm{EF}_{i}$ related to Product ${ }_{\mathrm{i}}$ estimated in kilograms of $\mathrm{CO}_{2}$ eq per kilogram of product.

Here, some assumptions have been made since there is not yet a life cycle EF for all the existing materials/products. For instance, waste, slag, and other similar subproducts have been granted an EF equal to zero because they have already fulfilled the uses for which they were produced. Another typical case is the existence of comparable products for which only one or a few of them have life cycle EF, in which case an average value has been granted to their like. In general, the methodology employs three EFs to offer a range for the emissions, corresponding to the lowest, the highest and the average EF of the products in each category.

The emissions inventory reckoning for trade activity with the rest of Spain requires further assumptions due to the lower amount of product categories presented in its data source. Therefore, it is assumed that the structure of trade from/to the RW behaves consistently to those of the RC; in other words, that the EF of a "rest of the country" category of products can be estimated as the weighted average of the EF of the "products imported" (or exported) from the RW_- TARIC category (Integrated Tariff of the European Union) - and associated in turn to a registered category for the rest of the country classification_— NACE 93 (Nomenclature Générale des Activites Économiques dans les Communautes Européennes). As a result, the EF for each regional product category exported and imported turns out to be different.

A specific but clarifying case example would be for instance an EF with a life cycle approach for electricity imports, which has been estimated according to the electricity generation mix in Spain during the key years of the study (2005 and 2016), measuring this factor in $\mathrm{kg} \mathrm{CO}_{2}$ eq/MWh.

Thus, an emission factor has been assigned to $93.8 \%$ of trade flows with the RW in terms of volume of products (94.0\% of imports; $93.6 \%$ of exports). These results have been extrapolated for the $100 \%$ of trade flows. In the case of trade with the rest of Spain, an estimated emission factor is available for $100 \%$ of the materials/products. In total, there is an associated EF, estimated or registered, for $99.5 \%$ of imports and $98.9 \%$ of exports. 
The second phase consists of estimating the GHG emissions related to the transport of products. This stage of the process requires identifying the disaggregated origins of imports (from RW and RC). It is also necessary to include the primary means of transport that have been utilized to reach the destination territory. The different means of transport included in the foreign trade statistical analysis are: maritime, rail, road, air, postal shipments, fixed transport facilities, inland navigation and own propulsion. ${ }^{1}$ In the case of regional trade, these are maritime, rail, road, air, and energy.

Trade transportation between Basque Country's provinces has not been considered here, as this figure is included in the TBI of GHG emissions. Finally, the emissions associated with export transportation are not considered here since, according to the present methodological proposal, the responsibility for the export transportation emissions corresponds to the buyers of such products.

Several assumptions have also been made in this phase. The most relevant is that the same EFs have been considered for the means of transport, regardless of its origin or nationality. Moreover, although the initial objective was to achieve a greater disaggregation of the EF by means of transport_—e.g., to distinguish emissions from different types of ships - the available data were scarce, thus dismissing this possibility.

In the case of maritime transport, EFs were only used for bulk vessels. For rail and air transport, the EF linked to cargo trains and cargo planes was used. ${ }^{2}$ For road transport, different options were considered depending on the size and the emission regulation followed by the truck (ranging from 3 to $6^{3}$ Euros). Regarding transport by inland navigation, the emission factor of barges is available, while for self-propelled vehicles or rigid trucks, it was considered the EF of a van from the Statistical Body of the Department of Economic Development and Infrastructure of the Basque Country (Basque Government, 2018a).

Finally, for postal services, the average of the EF of road and air transport has been applied because, although the logistics of postal services can include all means of transport, the most common ones are air and road (World Trade Organization, 2010).

The analysis of the data showed that for certain situations, the means of transport through which a particular commodity arrived at the Basque Country might not be consistent with its origin. For example, specific merchandise that arrived from Australia had assigned road transportation. This is due to the elaboration system of the statistics between Member States__ the Intrastat System—which indicates the last means of transport with which the imported goods entered the territory. For this study, in those cases in which the merchandise came by truck from a geographical place beyond Turkey and the Middle East, the means of transport assigned was maritime. ${ }^{4}$

The emissions associated with the transport of imports to the final destination were then calculated as:

$$
\text { Transport emissions }=\sum_{t=1}^{T} \sum_{c=1}^{C} \text { imports }_{t, c} \times \text { distance }_{t, c} \times \mathrm{EF}_{t}
$$

\footnotetext{
1 Those vehicles in which the driver's cabin and the trailer are an indivisible part of the same structure (TRANSGESA, 2018).

2 Cargo planes do not carry passengers (Moldtrans, 2018).

${ }^{3}$ EURO is a European regulation applicable to trucks whose objective is to develop vehicles with lower environmental impact in terms of emissions.

4 This modification affected a total of 85,000 tons of products, from 94 countries.
} 


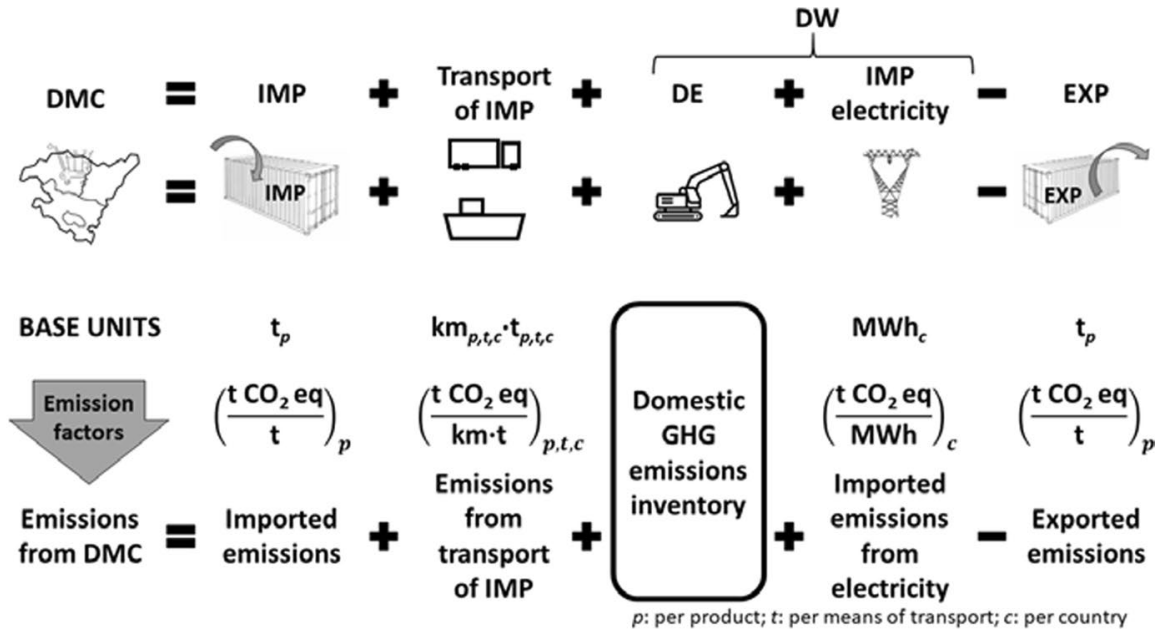

Fig. 2 Material flows in CBI. Source: the authors

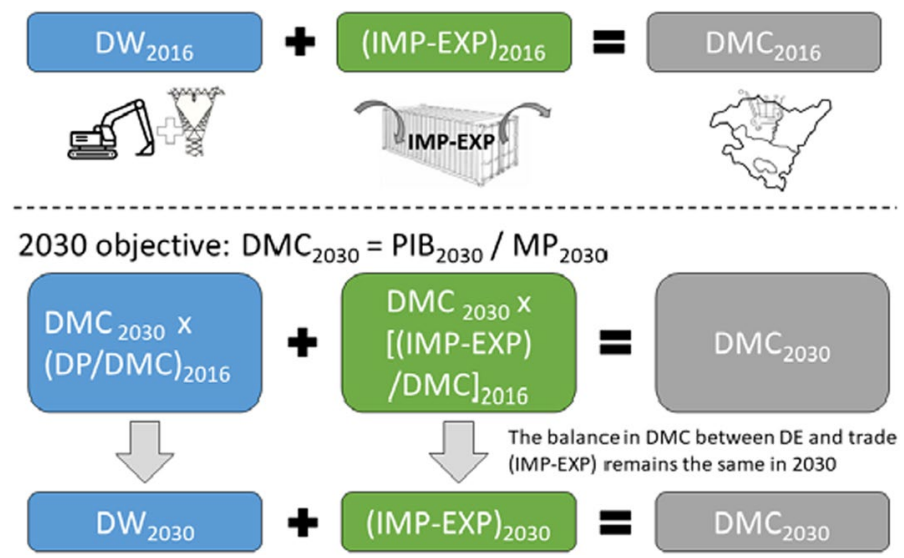

Fig. 3 Estimated volume of net imports and DW in 2030. Source: the authors based on the 2016 structure

where imports tr,c refers to the number of imports from country $c$ using transport $t$ (in kilograms); distance ${ }_{t, c}$ is the distance from country $c$ using transport $t$ (in kilometers); and $\mathrm{EF}_{t}$ is the $\mathrm{EF}$ associated with transport $t$ (in kilograms of $\mathrm{CO}_{2}$ eq per ton-kilometer traveled).

The third phase is to construct the CBI, which includes both the DW (taken from GHG TBI+ electricity imports) and the import-export GHG flows from previous phases, where import emissions include both those of products and those of their international transport (see Fig. 2).

Thus, this stage implies the development of a tool to analyze the impact of different future scenarios and policies. Given the objectives of this research, it is analyzed the 


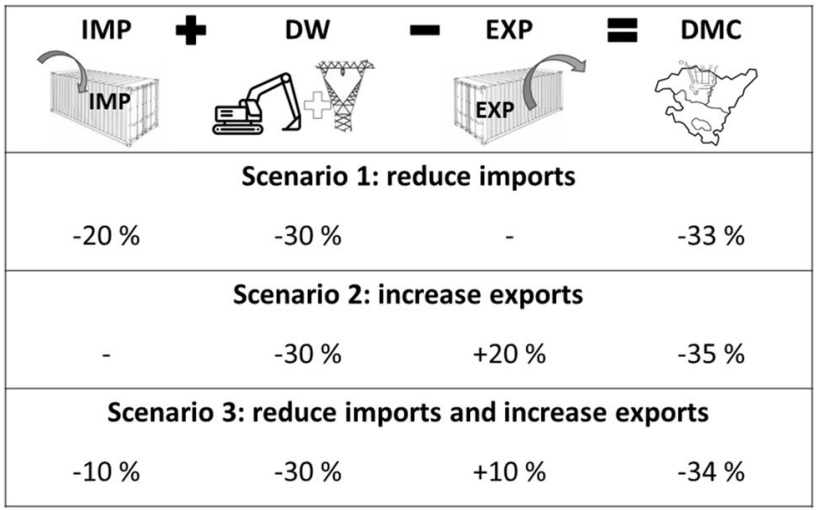

Fig. 4 Scenarios to 2030 of distribution of the reduction of the DMC. Source: the authors

impact of reaching two different objectives, an increase in the recycling rate and the goal of $\mathrm{MP}^{5}$ level by 2030 in terms of GHG emissions (see Fig. 3).

These variables are related by:

$$
\mathrm{MP}=\frac{\mathrm{GDP}}{\mathrm{DMC}}
$$

where GDP is the gross domestic product of the analyzed region and DMC is its domestic consumption of materials.

Based on the previous estimates, three scenarios have been proposed to calculate the impact that the reduction of the DMC will have on GHG emissions. All of them maintain the same reduction in the DW since it is the current preset territorial political objective. In the first scenario, the additional reduction in DMC is the consequence of reducing imports. The second scenario considers an increase in exports to further reduce DMC. In the third one, the additional reduction occurs through a mix of a decrease in imports and an increase in exports. The different scenarios are depicted in Fig. 4.

Therefore, through this methodological approach, it seems to be possible to analyze the impact of pre-established SDGs and circular economy territorial policies in terms of GHG emissions. For instance, those circular economy strategies aimed to reduce material and associated embodied environmental flows, which are present in C-Intereg (2019) and have been proposed by Stephan et al. (2020). These strategies impact the quantities in the input/ output tables of imported and exported products as well, which can be transformed into GHG emissions through the previous methodology, providing the needed GHG emission decrements in figures as a result of each circular economy strategy carried out.

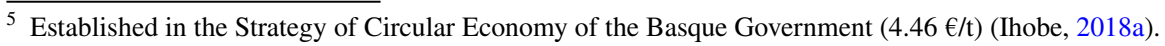


Table 1 Total $\mathrm{CO}_{2}$ eq emissions of imports transportation (million tons in 2016)

\begin{tabular}{lllll}
\hline $\begin{array}{l}\text { Origin of the } \\
\text { imports }\end{array}$ & $\begin{array}{l}\text { Total imports (million } \\
\text { tons) }\end{array}$ & $\%$ & $\begin{array}{l}\text { Average total emissions (mil- } \\
\text { lion tons } \mathrm{CO}_{2} \text { eq) }\end{array}$ & $\begin{array}{l}\text { Average EF } \\
\text { (tons of } \mathrm{CO}_{2} \\
\text { eq/t) }\end{array}$ \\
\hline RC & 12 & 42 & 0.7 & 0.0589 \\
RW & 21 & 58 & 1.0 & 0.0479 \\
Total & 34 & 100 & 1.8 & 0.0563 \\
\hline
\end{tabular}

The methodology provides results in terms of a range of emissions. Thus, average values are shown for simplicity

Source: the authors

Table $2 \mathrm{CO}_{2}$ eq emissions by means of transport

\begin{tabular}{lccc}
\hline Means of transport & $\begin{array}{l}\text { Imports (thou- } \\
\text { sand tons) }\end{array}$ & $\begin{array}{l}\text { Total average emissions } \\
\text { (thousand tons } \mathrm{CO}_{2} \text { eq) }\end{array}$ & $\begin{array}{c}\text { Average } \mathrm{EF}_{(\mathrm{t} \mathrm{CO}} \\
\text { eq/t of merchandise) }\end{array}$ \\
\hline Postal services & 1.04 & 0.48 & 0.4605 \\
Fixed transport facilities & 0.02 & 0.01 & 0.8781 \\
Rigid truck or own propulsion & 0.48 & 1.11 & 23.204 \\
Air & 14.21 & 84.80 & 59.672 \\
Sea & $18,456.76$ & 518.83 & 0.0281 \\
Road & $14,040.08$ & $1,108.68$ & 0.0790 \\
Railway & $1,134.04$ & 36.31 & 0.0320 \\
Inland navigation & 0.01 & 0.0004 & 0.0341 \\
Total & $33,646.65$ & $1,750.22$ & 0.0520 \\
\hline
\end{tabular}

Source: the authors

\section{Results}

This section presents the main results obtained with the approach described in the previous section. As mentioned before, one of the advantages of this complementary CBI approach is that the international transport emissions can be allocated to the agents in the receiving countries which are, ultimately, the responsible of the associated emissions of products. Besides, these emissions can be distinguished by their origin and the means of transport employed.

In this regard, in the case of the Basque Country, the total emissions generated due to the transportation of materials and products imports from the RC and the RW were around 1.8 million tons of $\mathrm{CO}_{2}$ eq in 2016, as it is detailed in Table 1.

The larger volume of emissions from the RW, compared to those associated with the RC imports, is primarily produced due to the longer distances traveled by materials/products from origin to destination territory. The average EF for the RW imports is significantly lower (19\%) than the average EF for RC imports. This is due to the means of transport employed, which is predominantly road transportation for RC. This is one of the most pollutant means and significantly higher than sea transport, which dominates RW imports.

According to this case study, $99.9 \%$ of the imported goods entered the Basque Country via three routes, which were sea $(54.8 \%)$, road $(41.7 \%)$, and rail (3.4\%). Moreover, 


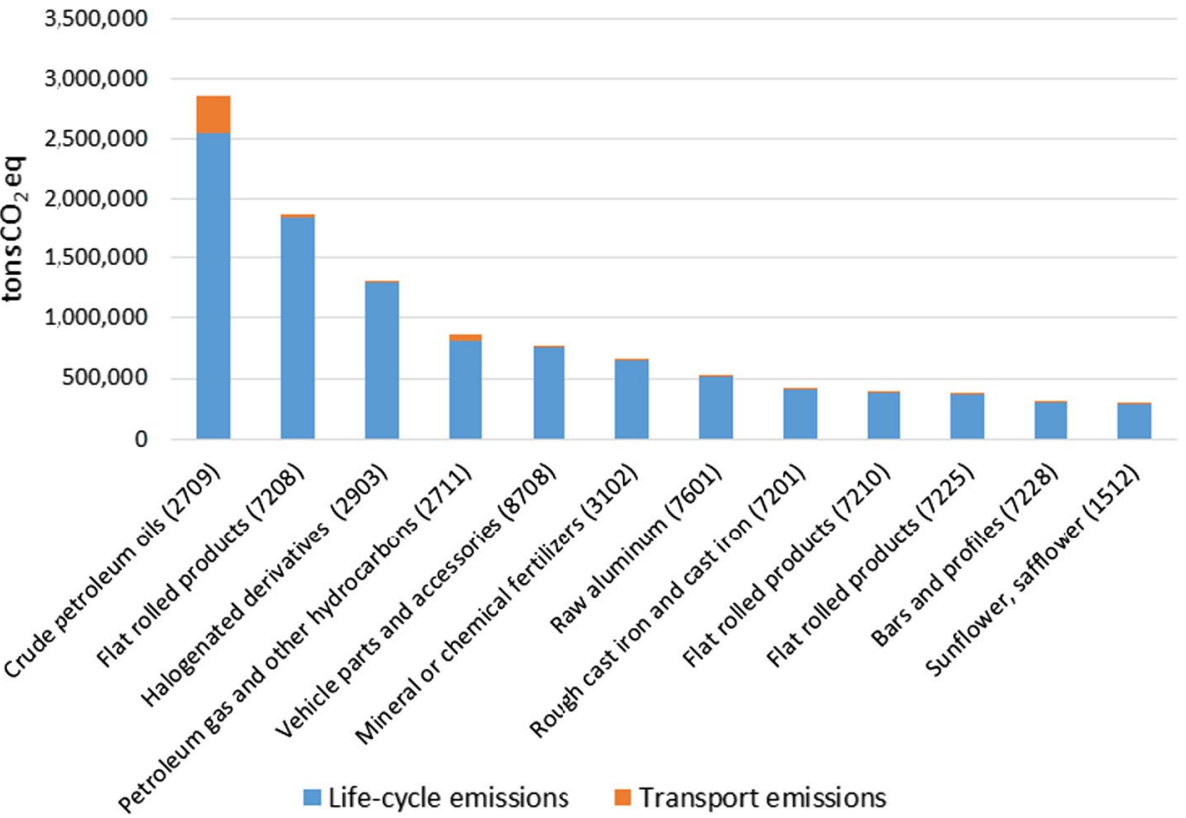

Fig. 5 Imported products with more emissions related (life cycle/transport) tons of $\mathrm{CO}_{2}$ eq. Source: the authors

97.8\% of emissions came as well from three means of transport: road (63\%), sea (30\%), and air (5\%). Air transport has by far the highest emission factor, 2.5 times higher than the second transport mean—which was rigid truck or own propulsion—and 6.8 times than the third one (fixed transport facilities). However, the impact of air transport on total global emissions turn out to be notorious, but not really significant due to its very reduced use. In contrast, navigation in both sea and inland are two of the lowest EF among the main means of transport (see Table 2).

Additionally, the large portion of sea imports in the count significantly reduces the impact of the Basque Country's transport-related emissions. This could be further incremented in the case of the RC transport with a higher use of rail and, in the few circumstances in which local geography allows it, inland shipping. Similarly, for the RW count, maritime and rail transports should be particularly promoted in those origins from which the proportion of road transport happens to be more salient, such as in Europe. In the long term, road transport would still be relevant for the final delivery-which in this methodology only appears in cross-border trading-where less emitter vehicles, such as electric vans, could be employed.

On the other hand, this approach can provide inputs to prove to policy makers which products are the most prominent in terms of global GHG emissions. In the Basque Country case, this study concluded that the most relevant group of products were those related to crude oil and its derivatives, as well as those from the metallurgical industry, in terms of both transportation and life cycle emissions. This might potentially facilitate the adoption of specific and more focused sectoral policies to achieve a cost-effective overarching territorial reduction of GHG emissions (Fig. 5). 
Table 3 Basque Country CBI emissions (2016, millions of tons of $\mathrm{CO}_{2}$ eq)

\begin{tabular}{llllrr}
\hline Origin & Imports & $\begin{array}{l}\text { Transport of } \\
\text { imports }\end{array}$ & Exports & TBI & CBI \\
\hline RC & 18.5 & 0.7 & 17.0 & - & - \\
RW & 22.2 & 1.0 & 27.1 & - & - \\
Total & 40.8 & 1.8 & 44.1 & 19.8 & 18.2 \\
\hline
\end{tabular}

Source: the authors

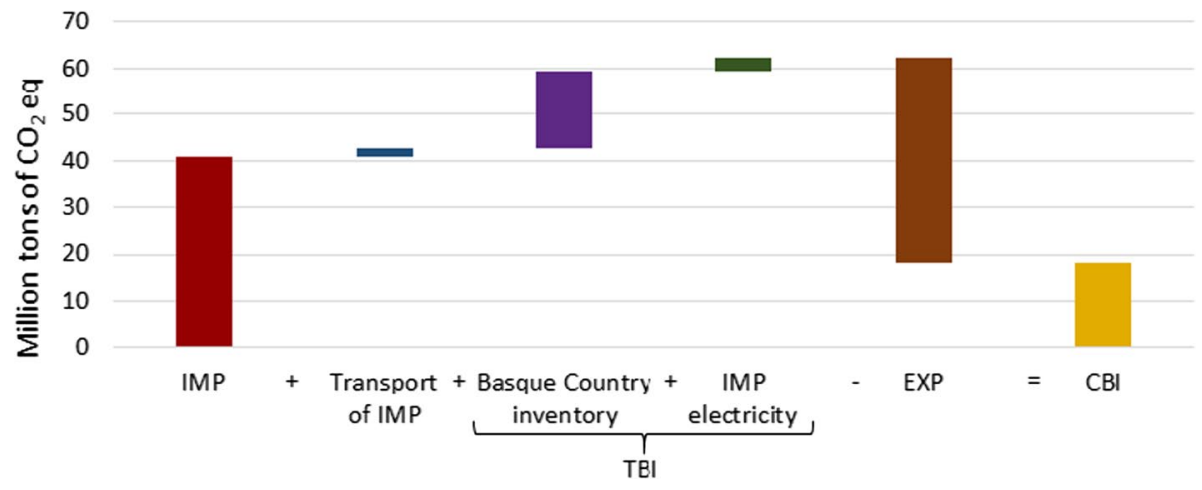

Fig. 6 Emissions related to consumption in million tons of $\mathrm{CO}_{2}$ eq for the Basque Country. Source: the authors

From this CBI perspective, the Basque Country presents an excellent balance between imports and exports emissions (see Table 3). Emissions due to transport represent around $4.6 \%$ of GHG emissions from imports pertaining to the RW and $4.1 \%$ for imports from the RC. This means that transport does not seem to be the main problem in terms of GHG emissions, given its weight in total emissions, although its adverse environmental impact cannot be disregarded (see Fig. 6).

In this sense, with a population of 2,176,577 inhabitants as of December 31, 2016, the emission per capita in the Basque Country was 8.4 tons/inhabitant. This figure is higher than that presented for Scotland in 2012 by Pratt and Lenaghan (2015), where the authors estimated an emission per capita of 6.7 tons of $\mathrm{CO}_{2}$ eq per inhabitant for that nation, and way below the 14.7 tons of $\mathrm{CO}_{2}$ eq per capita calculated for Austria in 2011 by Steininger et al. (2018), or the 20 tons of $\mathrm{CO}_{2}$ eq of Flanders in 2017 by Vito (2017).

Finally, the last phase of the approach embraces the formulation of an impact analysis for current policies and different potential alternative scenarios. The policies are set according to the SDG and Circular Economy Strategy of the Basque Government by 2030, which comprise an increase in the recycling rate, a reduction in DW, and the achievement of the 2030 objective of material productivity. Each scenario includes a contrasting combination of constituents to achieve the corresponding reduction in DMC derived from these policies.

Hence, in the first scenario, a reduction of $23.9 \%$ in total CBI emissions is achieved through a decline of $0.4 \%$ in import of materials and a decrease of $1.3 \%$ in DW. Consequently, the emission abatement registered owing to the drop in DW happens to be higher 
Table 4 Emissions variations in different components for each scenario

\begin{tabular}{llll}
\hline Components of the scenarios & Scenario 1 $(\%)$ & Scenario 2 (\%) & Scenario 3 (\%) \\
\hline Imports (flows) & -0.40 & - & -0.20 \\
Exports (flows) & - & -0.60 & -0.30 \\
IMP-EXP (flows) & -0.40 & -0.60 & -0.50 \\
Reduction DW (flows) & -1.30 & -1.30 & -1.30 \\
Emissions reduction of TBI & -21.20 & -21.20 & -21.20 \\
Emissions reduction of CBI & -23.90 & -24.30 & -24.10 \\
\hline
\end{tabular}

Source: the authors

than that obtained as a result of the limitation of import flows. A comparable results structure is obtained for the other two scenarios.

To sum up, most of the potential emission reductions could come as a consequence of the economic fulfillment of the territorial emission reduction objectives, rather than a change in the structure of imports and exports; this would be in line, among others, with the core environmental objective of reducing GHG emissions in the Basque Country by $40 \%$ by 2030, using 2005 as baseline year. Table 4 illustrates the potential reduction of GHG emissions for the three different suggested scenarios by 2030.

Indeed, a capital share of this abatement would come from the achievement of territorial circular economy goals that would exceed expectations in terms of current preset objectives present in the Basque Strategy for Climate Change for 2030. In this sense, 15.2\% of the reduced production emissions would be obtained as a result of redirecting waste recycling. With regard to $\mathrm{CBI}$, it means that around $14.5 \%$ of the projected total reduction would be due to the accomplishment of waste targets.

Therefore, the results of the analysis using the proposed approach seem to indicate that compliance with territorial commitments both in terms of sustainable development and circular economy goals would lead to more significant emission reductions than the decline derived from reducing imports of goods or increasing product exports. Thus, figures seem to indicate that progress should be made along two lines: the purchase of products where production turns out to be more efficient regarding GHG emissions and the decrease of continental GHG emissions. The analysis of which countries employ lower-emitting means of production could be further incorporated into the model as data availability improves.

Finally, in order to contextualize the case analysis here studied, it has been elaborated a customized diagram which summarizes the material flows of the Basque Country economy (see Fig. 7). This diagram is completed with the average estimated emissions obtained with the recommended approach, including life cycle emissions of products and the expected emissions from transport of imported goods.

\section{Discussion}

The present research aims at developing a purposeful approach for estimating GHG emissions starting from a consumption-based perspective, which has been employed here to study the case of the Basque Country, an industrial region in the north of Spain. In this sense, this work is intended to shed light on how the attainment of material 


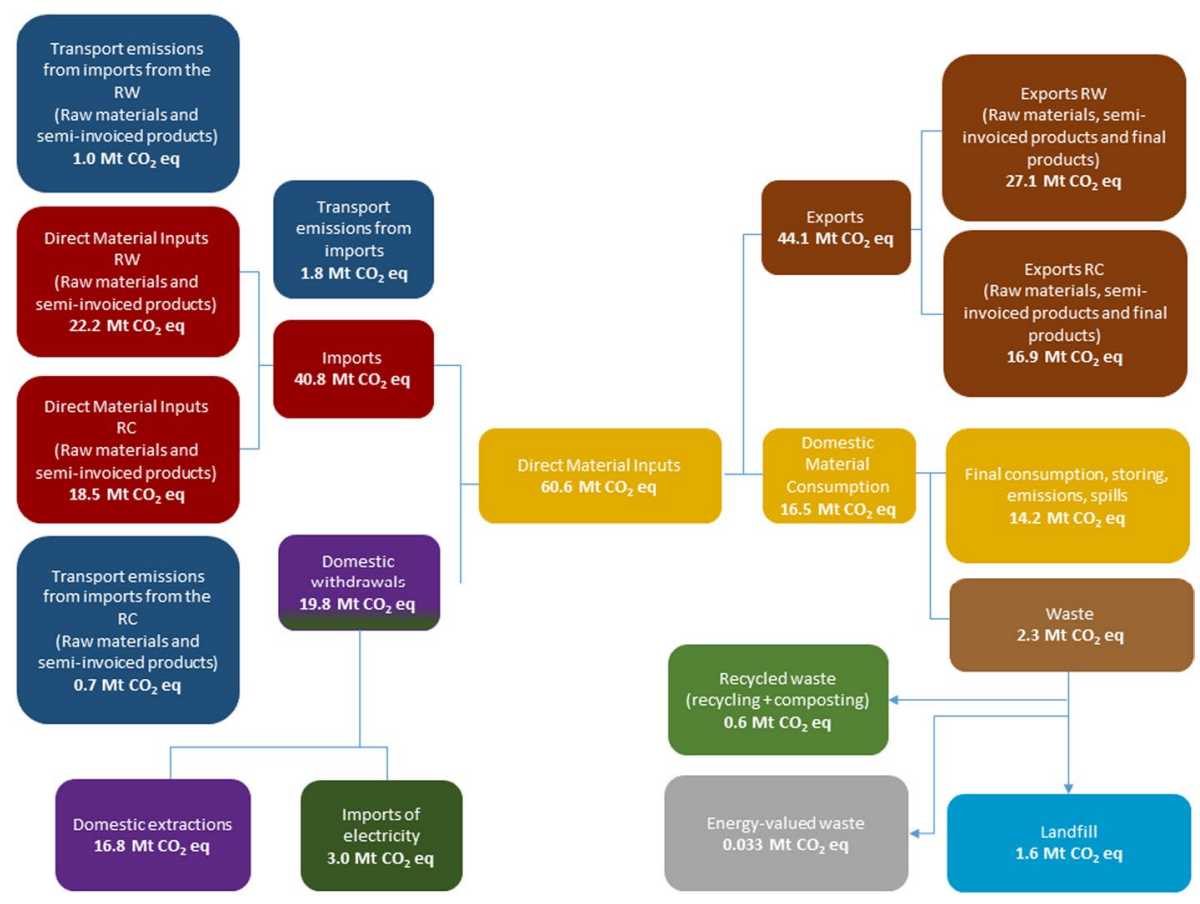

Fig. 7 Emissions flow of the Basque Country Diagram, 2016 Source: the authors

productivity (MP) ratio through potential alternative scenarios may impact to a greater or lesser extent-in terms of GHG emission-on the achievement of 2030 territorial sustainable development and circular economy goals on climate change.

Likewise, with its results, it seeks to contribute to the proposal and design of environmental policies, conducive to diminishing GHG emissions, by providing inputs to territorial governments and policy makers grounded in an advanced management of local materials flows structure, data, transportation, and evaluation of planned circular economy measures. In this sense, this work attempts to respond to the lack of studies that analyze temporal deviations between current emissions and future consumption (Chen et al., 2018), while encompassing fuel life cycle emissions (Yang et al., 2014).

According to its findings, the suggested approach here utilized does not seem to confirm that the consumption-based inventories (CBIs) and the production-based inventories (PBIs) tend to yield dissimilar accounts in industrial economies (hypothesis 1) since, regarding the former, the impact of its exports and imports is much lower than that of the DW. Indeed, this is particularly true for industrial economies in which the emissions from exported goods matches or surpasses those of imported goods. However, Davis and Caldeira (2009), as well as Jiborn et al. (2020), argue that CBIs may differ from traditional PBIs because of the $\mathrm{CO}_{2}$ emissions embodied in both imports and exports.

Given this result, and due to its simplicity, the use of PBIs for national binding agreements may still be practical, but not realistic. That is because climate change embodies a global concern in which consumers from all over the world play a predominant 
role as responsible agents. Furthermore, the CBI turns out to be a necessary approach for the design, establishment, and implementation of global international trade policies, such as the border tax adjustments on carbon emissions, as suggested by Peters (2008) and Barret et al. (2013). This perspective of valuation of GHG emissions inventory can undoubtedly cause greater awareness in society and trigger modifications in individual consumption behaviors (hypothesis 5).

Regarding whether the CBIs may increase if life cycle emissions factors are considered, as well as its imports and exports territorial structures-given that the use of emission factors varies between exported and imported products (hypothesis 2), valuable evidence emerges on the balance presumed to economies in developed countries in which the industry represents a high share of the GDP, such as the Basque one, where the value of its GHG imports is roughly the same of that of its exports. That is not the case of the UK, where the economy is based predominantly on services, as stated by Blakey and Hudson (2019). For the case of the Basque Country, the weight of the imported products represents a larger impact in its economy's carbon footprint compared to that of its domestic GHG emissions inventories, which are generally accounted for by the TBI.

On the other hand, through the analysis of this case study, the outcomes utilizing the suggested approach do not seem to validate the statement that the more globalized a territorial economy is, the more it will lead to higher emissions (hypothesis 3). It appears that the transport of products may scarcely contribute to global footprint when most imported products are transported by sea. What is more, these transport-related emissions can be further reduced in a territory with a more intense use of railway transport_—as suggested by Pritchard (2011) — whose reinforcement is being currently supported by the Spanish and Basque Governments.

Finally, related to the urgent need of sharing responsible environmental sustainability by consumers and producers (Bastianoni \& Pulselli, 2004; Ihobe, 2018b), this tool may help to understand what products, what origins and what means of transport are more intensive in emissions for a territory (hypothesis 4), enabling the allocation of these on the factual responsible agents and leading to the elaboration of more accurate policies and measures to achieve territorial sustainable development and circular economy goals linked to GHG emissions (hypothesis 6).

\section{Conclusion}

From a theoretical perspective, the present work provides interesting contributions to the methodological scopes with which GHG emissions inventories are accounted for; particularly for the corpus of research focused on how these can be utilized as key tools for tracking progress and achieving territorial sustainable development and circular economy goals associated with the reduction of GHG emissions, enriching the current set of knowledge primarily used to design and implement effective local policies on this subject. Furthermore, this methodology can be applied to cities, regions, and countries whenever they have material flows statistics and TBIs or PBIs.

From a utilitarian perspective, the proposed CBI approach and the tools here utilized for its estimation provide valuable insights to regional policy makers and stakeholders into how to take more specific and deep measures on GHG emissions reduction, given the identification of their generation foci. 
In this sense, these measures could potentially center on how to stimulate environmental innovation and eco-design, increase the recovery of goods for remanufacturing and recycling, reduce the volume of waste being transported to landfills, and to promote low-carbon transportation of materials like maritime and rail-instead of road transport.

On the other hand, the proposed CBI approach brings forth supplemental figures that could be considered relevant and complementary to the other GHG inventory accountancy, such as the TBI or PBI, since these pay attention to dissimilar system boundaries or GHG mitigation strategies. Conversely, the suggested CBI approach enables to integrate a global perspective of the enormous climate challenge the world faces today with the urgent need of acting together in mutual cooperation, jointly implementing innovative mitigation strategies while balancing the relation between consumption, economy, and GHG emissions.

In addition, the propounded approach could be utilized as a complementary tool to those innovatory MRIOA and EE-MRIOA approaches. Besides, products could be linked to activities to know where the emissions are being generated.

Finally, further research could focus on developing long-term models that analyze the evolution of GHG emissions related to certain sets of products and the impact that specific circular economy measures produce on these goods. In this vein, several tendencies that can be expected in the medium term could be incorporated into the model; for instance, the diminishment of EFs assigned to the majority of the products due to efficiency gains, the substitution of products for others with lower carbon intensity, the lessening of material inputs due to circular economy measures, etc.

\section{Limitations}

Despite the relevance of these research findings, several limitations have to be observed, particularly for the inherent methodological limitations regarding the partial availability of certain data.

Firstly, this fact implies some assumptions that have been made in the study about specific constituents such as certain EFs, whose territorial availability in terms of product diversity and country of origin shall be improved in future years. The creation of new concerted international policies, such as those regarding border tax adjustments on carbon emissions, could make policy makers realize the current need of developing these country datasets.

Secondly, a subject that raised certain challenges to the research happened to be the way of presenting imports and exports data from or to the rest of Spain. In this study case, the sectoral analysis of interregional flows of goods, which uses the NACE 93 classification, had to be passed to TARIC product codes. Consequently, a reasonable loss of precision in the assignment of emission factors between activities, products, and waste, among others, has to be considered here.

Thirdly, another data limitation refers to the transport recording, which registers only one journey for any product. As a result, the total transport distance of a good might be more significant than that appearing in the records.

Lastly, the absence of disaggregated information by economic sectors and the nonuse of a sectoral model for economy limit the potential of findings as inputs to define and implement more precise circular economy policies and actions within specific sectors. 
Authors' contributions Macarena Larrea Basterra contributed to conceptualization, methodology, validation, writing-original draft preparation and reviewing. Roberto Álvaro Hermana contributed to software, data curation, validation, writing-reviewing and editing; Nuria Ceular-Villamandos contributed to conceptualization, methodology, writing-reviewing and editing. Noel M. Muniz contributed to conceptualization, methodology, writing-reviewing and editing.

Funding Open Access funding provided thanks to the CRUE-CSIC agreement with Springer Nature. The authors would like to thank the Basque Government Public Society for Environmental Management, Ihobe, for its financial support and knowledge transfer in this research.

\section{Declarations}

Conflict of interest The authors declare that they have no known competing financial interests or personal relationships that could have appeared to influence the work reported in this paper.

Open Access This article is licensed under a Creative Commons Attribution 4.0 International License, which permits use, sharing, adaptation, distribution and reproduction in any medium or format, as long as you give appropriate credit to the original author(s) and the source, provide a link to the Creative Commons licence, and indicate if changes were made. The images or other third party material in this article are included in the article's Creative Commons licence, unless indicated otherwise in a credit line to the material. If material is not included in the article's Creative Commons licence and your intended use is not permitted by statutory regulation or exceeds the permitted use, you will need to obtain permission directly from the copyright holder. To view a copy of this licence, visit http://creativecommons.org/licenses/by/4.0/.

\section{References}

Agencia Tributaria. (2019). Estadísticas de Comercio Exterior. https://www.agenciatributaria.es/AEAT.inter net/Inicio/La_Agencia_Tributaria/Aduanas_e_Impuestos_Especiales/_Presentacion/Estadisticas_de_ Comercio_Exterior/Estadisticas_de_Comercio_Exterior.shtml. Accessed 27 Oct 2020.

Ahmad, N., \& Wyckoff, A. (2003). Carbon dioxide emissions embodied in international trade of goods (OECD Science, Technology and Industry Working Papers ed.) Organisation for Economic Co-operation and Development (OECD). https://www.oecd-ilibrary.org/docserver/421482436815.pdf?expires= $1584483202 \& \mathrm{id}=\mathrm{id} \&$ accname $=$ guest $\&$ checksum $=57 \mathrm{E} 3 \mathrm{BD} 8401 \mathrm{C} 27 \mathrm{~A} 05823773 \mathrm{D} 0 \mathrm{D} 23 \mathrm{D} 85 \mathrm{~A} 4$

Barrett, J., Peters, G., Wiedmann, T., Scott, K., Lenzen, M., Roelich, K., \& Le Quéré, C. (2013). Consumption-based GHG emission accounting: A UK case. Climate Policy. https://doi.org/10.1080/14693062. 2013.788858

Basque Government (2018a). Basque Country 2030: Basque contribution to the 2030 Agenda for Sustainable Development.

Basque Government (2018b). Circular Economy Strategy of Euskadi 2030. https://www.euskadi.eus/conte nidos/documentacion/economia_circular/es_def/adjuntos/EstrategiaEconomiaCircular2030.pdf. Accessed 17 Dec 2020.

Bastianoni, S., \& Pulselli, F. M. (2004). The problem of assigning responsibility for greenhouse gas emissions. Ecological Economics, 49(3), 253-257.

Blakey, J., \& Hudson, M. (2019). UK's net-zero ambition must count all emissions, not just in-country. https://energypost.eu/uks-net-zero-ambition-counting-all-emissions-not-just-in-country/uks-net-zeroambition-must-count-all-emissions-not-just-in-country-2/. Accessed 27 Oct 2020.

Broekhoff, D., Erickson, P., \& Piggot, G. (2019). Estimating consumption-based greenhouse gas emissions at the city scale. Stockholm Environment Institute. https://www.sei.org/wp-content/uploads/2019/03/ estimating-consumption-based-greenhouse-gas-emissions.pdf. Accessed 27 Oct 2020.

C40. (2018). Consumption-based GHG emissions of C40 cities. London: C40 Cities Climate Leadership Group. https://www.c40.org/researches/consumption-based-emissions. Accessed 28 Oct 2020.

Chandrakumar, C., McLaren, S. J., Malik, A., Ramilan, T., \& Lenzen, M. (2019). Understanding New Zealand's consumption-based greenhouse gas emissions: An application of multi-regional input-output analysis. The International Journal of Life Cycle Assessment, 25, 1323-1332.

Chen, Z. M., Ohshita, S., Lenzen, M., Wiedmann, T., Jiborn, M., Chen, B., Lester, L., Guan, D., Meng, J., Xu, S., Chen, G., Zheng, X., Xue, J., Alsaedi, A., Hayat, T., \& Liu, Z. (2018). Consumption-based 
greenhouse gas emissions accounting with capital stock change highlights dynamics of fast-developing countries. Nature Communications. https://doi.org/10.1038/s41467-018-05905-y

C-Intereg. (2019). Comercio Interregional. https://www.c-intereg.es/. Accessed 27 October 2020.

Davis, S. J., \& Caldeira, K. (2009). Consumption-based accounting of $\mathrm{CO}_{2}$ emissions. PNAS. https://doi. org/10.1073/pnas.0906974107

ecoinvent. (2019). ecoinvent 3.5 Database. Released August, 2018. https://www.ecoinvent.org/database/ ecoinvent-35/ecoinvent-35.html. Accessed 11 Mar 2019.

Edens, B., Delahye, R., van Rossum, M., \& Schenau, S. (2011). Analysis of changes in Dutch emission trade balance(s) between 1996 and 2007. Ecological Economics. https://doi.org/10.1016/j.ecolecon. 2011.07.006

European Commission. (2019). Communication from the commission to the European parliament, the European council, the council, the European economic and social committee and the committee of the regions. The European green deal. https://ec.europa.eu/info/sites/info/files/european-greendeal-communication_en.pdf. Accessed 27 Oct 2020.

European Commission (2020a). Stepping up Europe's 2030 climate ambition. Investing in a climateneutral future for the benefit of our people. https://eur-lex.europa.eu/legal-content/en/ALL/?uri= CELEX\%3A52020DC0562. Accessed 27 Oct 2020.

European Commission (2020b). A new Circular Economy Action Plan. https://ec.europa.eu/commission/ presscorner/api/files/document/print/en/ip_20_420/IP_20_420_EN.pdf. Accessed 27 Oct 2020.

Eurostat. (2017). Glossary: Material flow indicators. https://ec.europa.eu/eurostat/statistics-explained/ index.php/Glossary:Material_flow_indicators. Accessed 27 Oct 2020.

Eurostat. (2020b). New Eurostat visualization tool for the circular economy. https://ec.europa.eu/euros tat/en/web/products-eurostat-news/-/DDN-20200311-2?inheritRedirect=true\&redirect=/eurostat/ en/news/whats-new. Accessed 27 Oct 2020.

Eurostat (2020a). The domestic material consumption (DMC). http://ec.europa.eu/eurostat/tgm/table.do? $\mathrm{tab}=$ table\&init $=1 \&$ plugin $=1 \&$ language $=$ en \&pcode $=$ t2020_rl110. Accessed 17 Dec 2020 .

Ihobe (2020). The Ihobe Contribution to the Sustainable Development Goals. Report 2020. Environmental Management Agency from the Ministry of Economic Development, Sustainability and the Environment of the Basque Government. Accessed 17 Dec 2020 from https://www.ihobe.eus/publi cations/the-ihobe-contribution-to-the-sustainable-development-goals-2020-report

Ihobe. (2018a). Estrategia de Economía Circular. Objetivos Estratégicos -Propuesta de valores objetivo. Accessed 27 Oct 2020.

Ihobe. (2018b). Economía circular en la industria del País Vasco. Diagnóstico. www.ihobe.eus. Accessed 27 Oct 2020.

IPCC. (2019). IPCC 2019 Refinement to the 2006 IPCC Guidelines for National Greenhouse Gas Inventories. Accessed 20 Dec 2020 from https://www.ipcc.ch/report/2019-refinement-to-the-2006-ipccguidelines-for-national-greenhouse-gas-inventories/

Jiborn, M., Kulionis, V., \& Kander, A. (2020). Consumption versus technology: Drivers of global carbon emissions 2000-2014. Energies. https://doi.org/10.3390/en13020339

Kitzes, J., Peller, A., Goldfinger, S., \& Wackernagel, M. (2007). Current methods for calculating national ecological footprint accounts. Science for Environment \& Sustainable Society, 4(1), 1-9.

Larrea Basterra, M., \& Álvaro Hermana, R. (2019). Economía circular y cambio climático. https://www. orkestra.deusto.es/images/investigacion/publicaciones/informes/cuadernos-orkestra/200020-emisi ones-GEI-econom\%C3\%ADa-circular.pdf. Accessed 27 Oct 2020.

Larsen, H. N., \& Hertwich, E. G. (2009). The case for consumption-based accounting of greenhouse gas emissions to promote local climate action. Environmental Science \& Policy, 12(7), 791-798.

Lenzen, M., Murray, J., Sack, F., \& Wiedmann, T. (2007). Shared producer and consumer responsibility-theory and practice. Ecological Economics, 61(1), 27-42.

Moldtrans. (2018). La capacidad de los aviones de carga. https://www.moldtrans.com/la-capacidad-losaviones-carga/

Mont, O., \& Bleischwitz, R. (2007). Sustainable consumption and resource management in the light of life cycle thinking. European Environment, 17(1), 59-76.

Peters, G., \& Solli, C. (2010). Global carbon footprints: Methods and import/export corrected results from the Nordic countries in global carbon footprint studies, Nordic Council of Ministers.

Peters, G. P. (2008). From production-based to consumption-based national emission inventories. Ecological Economics, 65(1), 13-23.

Peters, G. P., \& Hertwich, E. G. (2006). Pollution embodied in trade: The Norwegian case. Global Environmental Change, 16(4), 379-387.

Peters, G. P., \& Hertwich, E. G. (2008). Post-Kyoto greenhouse gas inventories: Production versus consumption. Climatic Change. https://doi.org/10.1007/s10584-007-9280-1 
Pratt, K., \& Lenaghan, M. (2015). The carbon impacts of the circular economy. Technical report. https:// www.zerowastescotland.org.uk/sites/default/files/CIoCE\%20Technical\%20Report\%20-\%20FIN AL\%20-\%2015.06.15.pdf. Accessed 27 Oct 2020.

Pratt, K., Lenaghan, M., \& Mitchard, E. T. A. (2016). Material flows accounting for Scotland shows the merits of a circular economy and the folly of territorial carbon reporting. Carbon Balance and Management. https://doi.org/10.1186/s13021-016-0063-8

Pritchard, J. A. (2011). The potential of the railway to reduce greenhouse gas emissions. ECEE 2011 Summer Study: Energy Efficiency First: The Foundation of a Low-Carbon Society.

Reyes, B. (2012). Mathis Wackernagel y William Rees, Our Ecological Footprint: Reducing Human Impact on the Earth. New Society Publishers.

Steen-Olsen, K., Weinzettel, J., Cranston, G., Ercin, A. E., \& Hertwich, E. G. (2012). Carbon, land, and water footprint accounts for the European Union: Consumption, production, and displacements through international trade. Environmental Science \& Technology, 46(20), 10883-10891.

Steininger, K. W., Muñoz, P., Karstensen, J., Peters, G. P., Strohmaier, R., \& Velázquez, E. (2018). Austria’s consumption-based greenhouse gas emissions: Identifying sectoral sources and destinations. Global Environmental Change, 48, 226-242.

Stephan, A., Muñoz, S., Healey, G., \& Alcorn, J. (2020). Analyzing material and embodied environmental flows of an Australian university-towards a more circular economy. Resources, Conservation \& Recycling,. https://doi.org/10.1016/j.resconrec.2019.104632

Suh, S., Lenzen, M., Treolar, G. J., Hondo, H., Horvath, A., Huppes, G., Jolliet, O., Klann, U., Krewitt, W., Moriguchi, Y., Munksgaard, J., \& Norris, G. (2004). System boundary selection in life-cycle inventories using hybrid approaches. Environmental Science and Technology. https://doi.org/10.1021/es026 3745

TRANSGESA. (2018). Transporte terrestre y tipos de camiones. https://www.transgesa.com/blog/trans porte-terrestre-tipos-camiones. Accessed 10 Nov 2020.

Turner, K., Lenzen, M., Wiedmann, T., \& Barrett, J. (2007). Examining the global environmental impact of regional consumption activities-part 1: A technical note on combining input-output and ecological footprint analysis. Ecological Economics, 62(1), 37-44.

UN. (2015). Transforming our world: The 2030 agenda for sustainable development United Nations, Department of Economic and Social Affairs.

UNEP/SETAC. (2007). Life Cycle Management: A Business Guide to Sustainability. https://wedocs. unep.org/bitstream/handle/20.500.11822/7894/DTI0889PA.pdf?sequence=3\&amp $\% 3$ BisAllowed=. Accessed 15 Oct 2020.

UNFCCC. (2020). Reporting requirements. https://unfccc.int/process-and-meetings/transparency-and-repor ting/reporting-and-review-under-the-convention/greenhouse-gas-inventories-annex-i-parties/reportingrequirements. Accessed 27 Oct 2020.

USDN. (2020). Estimating consumption related emissions. https://sustainableconsumption.usdn.org/initi atives-list/estimating-consumption-related-emissions. Accessed 27 Oct 2020.

Gobierno Vasco. (2019). Emisiones de Gases de Efecto Invernadero. C.A. del País Vasco. 1990-2017. Departamento de Medio Ambiente, Planificación Territorial y Vivienda. https://www.euskadi.eus/ web01-a2ingair/es/contenidos/estadistica/amb_cc_gei/es_def/index.shtml Accessed 27 Oct 2020.

Vito. (2017). Two third greenhouse gas emissions of Flanders 'consumption produced aboard. https://vito. be/en/news/two-third-greenhouse-gas-emissions-flanders-consumption-produced-abroad. Accessed 27 Oct 2020.

WCED. (1987). Our common future. Oxford University Press, Oxford.

Wiedmann, T., Lenzen, M., Turner, K., Minx, J., \& Barret, J. (2007). Multiregional input-output modelling opens new opportunities for the estimation of ecological footprints embedded in international trade. International ecological footprint conference. Stepping up the pace: New developments in ecological footprint methodology. In: International Ecological Footprint Conference, Cardiff.

Wiedmann, T. (2009). A review of recent multi-region input-output models used for consumption-based emissions and resource accounting. Ecological Economics. https://doi.org/10.1016/j.ecolecon.2009.08. 026

World Trade Organization. (2010) Postal and courier services: Background note by the secretariat'. S/C/W/319. Unpub.

Yang, Z., Dong, W., Wei, T., Fu, Y., Cui, X., Moore, J., \& Chou, J. (2014). Constructing long-term (19482011) consumption-based emissions inventories. Journal of Cleaner Production, 103, 793-800.

Zero waste Scotland. (2015). The carbon impacts of the circular economy. Technical report. https://www. zerowastescotland.org.uk/sites/default/files/CIoCE\%20Technical\%20Report\%20-\%20FINAL\%20-\% 2015.06.15.pdf. Accessed 27 Oct 2020. 
Publisher's Note Springer Nature remains neutral with regard to jurisdictional claims in published maps and institutional affiliations.

\section{Authors and Affiliations}

\section{Macarena Larrea Basterra ${ }^{1,2}$ (D) Roberto Alvaro-Hermana ${ }^{1,2}$. Nuria Ceular-Villamandos ${ }^{3} \cdot$ Noel M. Muniz ${ }^{1,2}$}

Roberto Alvaro-Hermana

roberto.alvaro@orkestra.deusto.es

Nuria Ceular-Villamandos

nuria.ceular@uco.es

Noel M. Muniz

noel.muniz@orkestra.deusto.es

1 Deusto Business School, Universidad de Deusto, Av. de las Universidades, 24, 48007 Bilbao, Spain

2 Orkestra, Fundación Deusto, Av. de las Universidades, 24, 48007 Bilbao, Spain

3 Department of statistics and Operations Research, Business Organization and Applied Economics, Universidad de Córdoba, 14014 Córdoba, Spain 